\title{
A Content Analysis of Whistleblowing Policies of Leading European Companies
}

\section{Harold Hassink Meinderd de Vries Laury Bollen}

ABSTRACT. Since the introduction of the U.S. Sarbanes-Oxley Act in 2002 and several other national corporate governance codes, whistleblowing policies have been implemented in a growing number of companies. Existing research indicates that this type of governance codes has a limited direct effect on ethical or whistleblowing behaviour whereas whistleblowing policies at the corporate level seem to be more effective. Therefore, evidence on the impact of (inter)national corporate governance codes on the content of corporate whistleblowing policies is important to understand their indirect impact on whistleblowing behaviour. This study analyzes the contents of whistleblowing policies, and parts of corporate codes of conduct and codes of ethics, describing such policies of 56 leading European companies. By classifying the contents in seven categories, an exploratory framework was created. General contents often identified were: applicability to all employees, a group-wide scope and an authoritative tone. The most common general violations to report were breaches of internal policies and external regulations or laws. The more specific violations most frequently mentioned were criminal offences and dangers to health and safety or the environment. Contacts to report to were the direct or indirect supervisors, a compliance officer or a confidential "hotline" facility. A confidentiality guarantee was common and anonymous reporting was often possible, though sometimes discouraged. Protection against retaliation is stated by ensuring that retaliation will not happen, prohibiting it or making it punishable. The requirement of good faith was frequently given. Finally, investigation of the report was often guaranteed. Surprisingly little information is given on the treatment of whistleblowers reporting an unfounded complaint in good faith, or reporting a violation they were involved in. The study's findings are most relevant to companies without a whistleblowing policy or those that intend to benchmark their policies, and to pan-European standard setters.
KEY WORDS: business ethics, codes of conduct, codes of ethics, compliance, content, whistleblowing

\section{Introduction}

In the summer of 2005, a new corporate scandal came to light when the Dutch ING Bank had to reprimand its marketing director for "parking" millions of euros at advertising agencies for several years, thus artificially exceeding his budget. The scandal was instigated by whistleblowers who further accused the director of taking presents (like junkets) from these agencies, and of using cocaine during working hours. An internal investigation was conducted and no evidence for these claims was found. However, in the meantime the lack of a public response from ING enabled the accusations to turn into a smear campaign in the media. As a result, although the director's name was eventually cleared, his relationship with his employer had become so distorted that he was fired (De Financiële Telegraaf, August 12, 2005).

A widely used definition of whistleblowing is "the disclosure by organization members (former or current) of illegal, immoral, or illegitimate practices under the control of their employers, to persons or organizations that may be able to effect action" (Near and Miceli, 1985, p. 4). A more restrictive definition is (Jubb, 1999, p. 83):

Whistleblowing is a deliberate non-obligatory act of disclosure, which gets onto public record and is made by a person who has privileged access to data or information of an organization, about non-trivial 
illegality or other wrongdoing whether actual, suspected or anticipated which implicates and is under the control of that organization, to an external entity having potential to rectify the wrongdoing.

Jubb explicitly pictures whistleblowing as an act of dissent, which publicly implicates a company by externally disclosing wrongdoing. In response to scandals and the new legislation, however, an increasing number of companies have adopted whistleblowing policies that should make external disclosure unnecessary by solving the problem internally. These policies are examples of what Vandekerckhove and Commers (2004, p. 226) call institutionalized whistle blowing, defined as "the set of procedures allowing potential whistle blowers to raise the matter internally before they become whistle blowers in the strict sense". The concept of whistle blowers in the strict sense refers to Jubb's narrow definition.

Scandals including Ahold, Parmalat, Enron and WorldCom triggered legislation such as the US Sarbanes-Oxley Act (SOX) of 2002, and a number of European laws and guidelines on good corporate governance. Legal protection of whistleblowers and the presence of internal whistleblowing policies play an important part in some of these. Existing literature suggests that corporate whistleblowing policies are more effective in affecting whistleblowing behaviour compared to regulatory changes such as the implementation of SOX. Therefore, to understand the indirect effect of regulations through corporate whistleblowing policies, it is important to understand the issues that are addressed in these policies. The present study analyzes the contents of whistleblowing policies, and parts of corporate codes of conduct and codes of ethics describing such policies, of 56 leading companies listed in Europe. The primary aim of the study is to increase our understanding of the nature of whistleblowing policies. This analysis is relevant for several reasons. First, the content of whistleblowing policies has a direct effect on its effectiveness (Lewis, 2002). Second, the results are relevant to understand the impact of recent regulatory changes on the content of corporate whistleblowing policies. Empirical evidence on this issue is important to understand the indirect impact of such regulations on whistleblowing behaviour. Furthermore, the results of the study have practical relevance because companies may use the findings of this study for benchmarking purposes; to position themselves and to identify avenues for improvements.

This paper is organized as follows. The next paragraph describes recent regulatory developments in Europe. Subsequently, the existing literature on codes of ethics and whistleblowing policies will be discussed to address the relationship between corporate ethical codes, whistleblowing policies and whistleblowing behaviour. Next, the empirical results on the policies' contents will be presented, followed by findings on the policies' nomenclature and contact persons. Finally, a conclusion and recommendations for future research will be given.

\section{Developments in whistleblowing regulation}

In the United States, after the Enron and WorldCom scandals, the Sarbanes-Oxley Act was implemented on July 30, 2002. Section 301 of SOX states:

Each audit committee shall establish procedures for the receipt, retention, and treatment of complaints received by the issuer regarding accounting, internal accounting controls, or auditing matters; and the confidential, anonymous submission by employees of the issuer of concerns regarding questionable accounting or auditing matters.

This part effectively requires institutionalized whistleblowing, and companies are free to apply these procedures to other kinds of violations covered by codes of conduct or ethics policies. Section 806 of the Act protects whistleblowers from retaliation by giving them the opportunity of civil action after reporting a violation of securities laws to a law enforcement agency, Congress or an internal person with supervisory authority. Finally, Section 1107 makes retaliation against employees disclosing a Federal offence (possibly) committed by the company to a law enforcement officer, a criminal act to be punished with a fine or a maximum of 10 years of imprisonment.

Prior to SOX, Federal whistleblower statutes only applied to the public sector, or to more specific kinds of violations like environmental pollution and 
inadequate safety measures. SOX is broader and more aggressive than these previous statutes (Salem and Franze, 2002).

In the U.K., the Public Interest Disclosure Act 1998 protects both internal and external disclosures from retaliation, but does not encourage companies to institutionalize whistleblowing. To this end, the Financial Services Authority introduced the Combined Code on Corporate Governance in July 2003. This code consists mainly of guidance and best practice suggestions and contains a provision on whistleblowing (FSA, 2003, p. 52):

The audit committee should review arrangements by which staff of the company may, in confidence, raise concerns about possible improprieties in matters of financial reporting or other matters. The audit committee's objective should be to ensure that arrangements are in place for the proportionate and independent investigation of such matters and for appropriate follow-up action.

The Combined Code does not have the status of law, but all U.K. companies listed on the London Stock Exchange are required by the Financial Reporting Council (FRC) "to report on how they have applied the principles of the code, and either to confirm that they have complied with the code's provisions or - where they have not - to provide an explanation" (FRC, 2005).

In the Netherlands, the Corporate Governance Code was drafted by a committee lead by Morris Tabaksblat, the former CEO of Unilever, and was adopted on December 9th, 2003. The "Tabaksblat Code" consists of general principles of good corporate governance that Dutch listed companies are required to apply, and best practice provisions that are regarded as elaborations of these principles which they may choose not to follow (Kennedy Van der Laan, 2005). The purpose of the code is to modernize Dutch corporate law and to increase the attractiveness of the Netherlands from an investment perspective (Ministry of Justice, 2004). The code became effective on January 1st, 2005 and Dutch listed companies are legally required to either apply the best practices that are incorporated in the code, or explain why they deviate from them. Companies that give a wellfounded explanation, approved by the shareholders, for non-compliance with best practice provisions and fulfil the underlying principle in another way, are still in compliance with the code (Tabaksblat, 2003). Whistleblowing is included in the code as best practice provision II.1.6 (CGC, 2003, p. 9):

The management board shall ensure that employees have the possibility of reporting alleged irregularities of a general, operational and financial nature in the company to the chairman of the management board or to an official designated by him, without jeopardising their legal position. Alleged irregularities concerning the functioning of management board members shall be reported to the chairman of the supervisory board. The arrangements for whistleblowers shall in any event be posted on the company's website.

In Belgium, the Code on Corporate Governance, drafted by the Lippens Committee and published on December 9, 2004, is similar in structure to the Tabaksblat Code in the Netherlands. It contains nine principles all companies should adhere to, and provisions describing how to apply the principles. Following the model of the U.K. Combined Code, Belgian listed companies "are expected to comply with these provisions or explain why, taking into account their specific situation, they do not comply" (CGC, 2004, p. 8). In addition, there are guidelines for interpretation and implementation of the provisions. These are not subject to the "comply or explain" system. The code's whistleblowing provision (CGC, 2004, p. 27), which is almost identical to the one in the U.K. Combined Code, states:

The audit committee should review the specific arrangements made, by which staff of the company may, in confidence, raise concerns about possible improprieties in matters of financial reporting or other matters. If deemed necessary, arrangements should be made for proportionate and independent investigation of such matters, for appropriate follow-up action and arrangements whereby staff can inform the chairman of the audit committee directly.

In Germany the Corporate Governance Code, introduced on February 26, 2002 by the Cromme Committee and amended on June 2, 2005, has more explicitly been given a power similar to law for part of its content, although it also follows the 
"comply or explain" line of thought (GCGC, 2002, p. 2):

The recommendations of the Code are marked in the text by use of the word "shall". Companies can deviate from them, but are obliged to disclose this annually. This enables companies to reflect sector and enterprise-specific requirements. Thus, the Code contributes to more flexibility and more self-regulation in the German corporate constitution. Furthermore, the Code contains suggestions, which can be deviated from without disclosure; for this the Code uses terms such as "should" or "can". The remaining passages of the Code not marked by these terms contain provisions that enterprises are compelled to observe under applicable law.

There is no whistleblowing provision in this code.

The national corporate governance codes of all other countries included in this study (i.e., Switzerland, France, Sweden) follow the "comply or explain" philosophy, but none of them contains a whistleblowing provision. Despite this apparent lack of interest outside the U.K., Belgium and the Netherlands in regulating whistleblowing policies on a national level, attempts have been made in France and Switzerland to introduce it into the financial sector. In 2005 the Commission Bancaire, the French banking regulator, made a number of proposals to amend Regulation 97-02, the current regulation on internal controls applying to both banks and investment firms. A non-compulsory whistleblowing process (whistleblowing is allowed if deemed necessary by the employee, but not required) was one of these proposals (PricewaterhouseCoopers, 2005). The new Regulation 97-02 has been effective since January 1st, 2006 (AFEP and MEDEF, 2003).

A similar recent action in Switzerland was less successful. In the spring of 2005, the Swiss Federal Banking Commission (SFBC) issued a draft Circular called "Internal Surveillance and Control", containing a whistleblowing clause. In August of the same year, the Swiss Bankers Association (SBA) rejected this clause on principle, stating it "would radically change the internal culture of banks as well as the atmosphere in the workplace" and "there are today other and more effective methods with which to control and manage risk" (SBA, 2005).
In an international context, SOX has to be followed by subsidiaries of US-based listed companies, and by European companies listed on the New York Stock Exchange. In France, however, this has proven to be problematic. On May 26, 2005, the French National Commission for Data Protection and Liberties (CNIL) decided that the anonymous whistleblower hotlines McDonald's and CEAC/ Exide Technologies wanted to implement as part of their new codes of conduct, were in violation of the Data Protection Law. Anonymous reporting through such mechanisms was regarded unfair collection of data, since the subject of the data is not informed. These hotlines were judged as disproportionate in relation to their objectives, and going too far in addition to the present French labour law providing the means to detect and punish violations of company rules (Dechert, 2005).

A similar decision was made against Wal-Mart in Germany by the Employment Court of Wuppertal on June 15, 2005. However, in this case the lawfulness of whistleblower hotlines in itself was not the issue. Wal-Mart had published a new Code of Business Conduct and Ethics, which contained a specific whistleblowing procedure including a hotline, but failed to consult the works council before implementation. The Court stated that both the mandatory conduct rules and the technical equipment for monitoring employee conduct, to be introduced as part of the hotline, required works council consent. No position was taken by the court on whether or not the hotline was legal according to German law (Eversheds, 2005).

The regulatory changes addressed in this section are all intended to change existing whistleblowing behaviour in the sense that they aim to facilitate the whistleblowing process and to protect the position of the whistleblower. However, existing literature (see next section) suggests that the impact of structural factors (such as regulations) is larger at a corporate level. Therefore, regulatory changes on actual whistleblowing behaviour may be most effective through corporate whistleblowing policies. To further address the role of policies and regulations on whistleblowing behaviour, the next section will discuss the existing literature on whistleblowing behaviour. 


\section{Theoretical background}

Existing theory on ethical behaviour suggests that personal characteristics (e.g., moral development, ego, locus of control) and situational (organizational) factors (i.e., organizational culture) have a significant effect on ethical behaviour (e.g., Jones, 1991; Trevino, 1986). This suggests that organizations can influence ethical behaviour either by screening their employees on their cognitive moral development or by creating an environment that reduces the likelihood of unethical behaviour (Trevino, 1986). Additionally, it is argued that most individuals search for guidance in ethical dilemmas outside themselves (Trevino, 1986). This suggests a role for ethical codes, which are written, distinct and formal documents that describe moral standards for individual and corporate behaviour (Schwartz, 2001). Nitsch et al. (2005) studied the reasons why employees fail to report violations in their companies, to propose a conceptual framework for studying the phenomenon of code violation non-reporting. The motivations for not reporting were classified in four categories: factual non-responsibility (people were not sure if there was a violation and/or how they should report it), moral non-responsibility (people believed it was not their duty to report the observed violation), consequential exoneration (fear of reprisals from the violator or the organization) and functional exoneration (reliance on personal morals, resulting from lack of faith in the administrative system). All these issues can be dealt with by means of a code of conduct. Ferrel and Gresham (1985) provide a contingency model of ethical behaviour that suggests that ethical codes will produce the highest level of compliance to ethical standards. Similarly, Trevino (1986) and Brass et al. (1998) argue that ethical codes can significantly reduce unethical behaviour within organizations. However, many scholars have argued that ethical codes have a limited impact on ethical behaviour in organizations. Although many companies have a code of conduct, many of them are merely paying lip service to the notion of encouraging ethical behaviour (e.g., Kjonstad and Willmott, 1995; Lindsay et al., 1996; Marnburg, 2000; O’Dwyer and Madden, 2006; Sims, 1991; Sims and Brinkmann, 2003; Weaver et al., 1999). Others (e.g., Brinkmann and Ims, 2003) have argued that the effectiveness of ethical codes depends on the method of implementation, the process of code revision, the existence of disciplinary procedures in case of violations and the procedures in place for seeking advice or reporting violations. With respect to the importance of the enforcement of ethical codes, Trevino and Victor (1992) argue that employees who are willing to monitor the behaviour of, and report misconduct by their peers may serve as an important control mechanism. Consequently, whistleblowing policies may play an important role in the effectiveness of codes of conduct in encouraging ethical behaviour.

Existing studies on whistleblowing have identified five types of factors that influence the likelihood of whistleblowing actions (Janssen, 2006):

1. Psychological factors: the psychological factors include features like organizational commitment and loyalty. For example, the more loyal an employee is to his company, the more likely it is that he will report organizational misbehaviour, as long as this is advantageous to his employer (see Larmer, 1992; Mesmer-Magnus and Viswesvaran, 2005; Miceli and Near, 1988; Street, 1995; Vandekerckhove and Commers, 2004). Overall, the findings of studies on whistleblowers' characteristics indicate that whistleblowers usually hold professional positions, have longer service, and are male. The link between organizational commitment and the intent to blow the whistle is unclear.

2. Cultural and ethical factors: individuals from certain nationalities and belonging to specific cultures perceive whistleblowing in another way than people from other cultures might (see Brody et al., 1998; Ergeneli, 2005; Gernon, 1993; Thomas and Miller, 2005). In general, studies on culture, nationality and ethics show significant diversity in the way people from different countries perceive whistleblowing. In this context, collectivism plays a major role, which means that the interest of the company is more important than that of the individual. Therefore, employees from Asian countries, like Japan and China, are more likely to blow the whistle than their Western counterparts, like Americans, are. Besides culture and nationality, a person's decision to blow the 
whistle is also influenced by the level in which a person perceives this action as ethical.

3. Structural factors, including policies and regulations concerning whistleblowing: If an organization pursues a policy that stimulates whistleblowing, an individual is more likely to actually blow the whistle. Given the focus of our study, the role of structural factors in whistleblowing behaviour will be discussed in more detail below.

4. Retaliation: when an individual faces harsh punishment for his reporting behaviour, or fears such effects, he will be discouraged in blowing the whistle (see Arnold and Ponemon, 1991; Dworkin and Baucus, 1998; Miceli and Near, 1994; Mesmer-Magnus and Viswesvaran, 2005; Near and Miceli, 1986) Generally, there is no clear link between retaliation and whistleblowing behaviour. It seems that most whistleblowers do not face any penalty, and therefore they do not fear such negative consequences to their actions.

5. Type of wrongdoing: the decision to blow the whistle depends on the type and severity of the wrongdoing (see Near et al., 2004).

With respect to the role of structural factors, the distinction between general policies, such as regulations, and corporate policies is essential. Schmidt (2005) argues that the fortification of external whistleblowing by regulation - either through direct rewards or through explicit protection from retaliation - creates possible negative effects since one cannot rule out the incentive for individuals to blow the whistle for purely opportunistic reasons. Also, statutory approaches that support internal whistleblowing by protecting employees from retaliation can set off opportunistic behaviour that negatively influences organizational efficiency. Internal whistleblowing, on the other hand, avoids hesitant effects on organizational efficiency and can bind the interests of an organization's managers and its stakeholders. It is, therefore, suggested to unite authentic legal measures to make use of self-regulation via governance codes of conduct and flexible sanctioning. Near et al. (1993) reviewed three sets of studies that investigated the effect of different whistleblowing policies. Legal sanctions regarding encouragement of whistleblowing turned out to be unsuccessful, while legalistic responses by organizations seemed to be somewhat more successful. One possible explanation for this finding is that the legal sanctions only focus on one interest group, being the organization, while the policies developed by the organizations themselves are intended to change both organizational behaviour as well as that of the potential whistleblower. Corporate whistleblowing policies that facilitate the internal reporting of suspicious behaviour as well as the protection of the whistleblower, shield the company from external whistleblowing, which in general is considered to be more detrimental to the company, the whistleblower (Callahan and Collins, 1992) and society at large (Dworkin and Near, 1997). Furthermore, managers who have introduced internal reporting procedures perceive them as contributing to their image as both an ethical and efficient organization (Lewis, 1997). Consequently, for general legal policies to be more effective, they preferably should result in subsequent changes in corporate policies to create an indirect effect on whistleblowing behaviour. With respect to the relation between legal policies and corporate policies, Near and Dworkin (1998) examined whether organizations changed their whistleblowing policies as a response to changes made in state statutes concerning whistleblowing. It turned out that only a fifth of the companies investigated established internal reporting procedures as a response to changes in state statutes. This suggests that legal policies do not necessarily transfer into changes in corporate legal codes. As a result, an analysis of the content of corporate whistleblowing policies is essential to assess the indirect effect of legal changes on whistleblowing practices.

With respect to the effectiveness of internal policies, empirical studies have found that companies with internal whistleblowing procedures experience a significant increase in the number of internal disclosures and a significant decrease in the number of external disclosures after implementation (Barnett et al., 1993). Also, these companies had significantly more internal disclosures than companies without such internal procedures. These results show that internal whistleblowing policies do result in an increased role of internal whistleblowing, which in general is preferred over external whistleblowing, both from an ethical and a practical point of view (see Barnett et al., 1993; Vandekerckhove and Commers, 2004; Van Es and Smit, 2003). 
In summary, knowledge on the content of internal whistleblowing policies is important to assess the indirect effects of recent changes in regulations and to increase our understanding of the effectiveness of these procedures to influence whistleblowing behaviour. In this context, a few studies have examined policy documents for a content analysis to identify common issues addressed in these documents without judging them for effectiveness. Gaumnitz and Lere (2002) analyzed the codes of ethics of 15 professional business organizations in the United States. Farrell and Cobbin (2000) investigated the codes of ethics of 57 national accounting organizations for their nomenclature, physical properties and contents, and compared them to the model code published by the International Federation of Accountants (IFAC). And for the top 200 of multinational companies, Kaptein (2004) conducted a similar analysis of the business codes of the 105 organizations that had such a code. None of these studies, however, explicitly addressed the issue of whistleblowing.

\section{Design of the study}

\section{Sample collection}

The primary research population of this study is the Ftse Eurotop-100, featuring the largest European listed companies. In early September 2005, all companies on this list were sent an e-mail with two questions: "Does your company have an explicit program for protection of whistleblowers?" and "If so, could you e-mail us the text of the program (either as part of the code of conduct or as a separate document)"? Specific policy documents as well as codes of conduct or ethics with a whistleblowing policy clause were deemed useful responses.

Four companies could not be e-mailed due to the lack of an e-mail service or technical difficulties with it. In three of these cases, a policy was found on their websites after all. Also, some companies were listed on the Eurotop-100 for two different countries or securities at once. Controlling for these double counts, only one e-mail was sent to these companies. In total, 95 e-mails were sent. Forty-seven companies $(50 \%)$ responded to the e-mail; ten of them refused to cooperate as a matter of policy, five indicated having no whistleblower policy and eight had a policy but would not disclose its details publicly. Twenty-four useful responses remained, suggesting a response rate of $25 \%$. Of these 24 , seven companies attached an internal policy document (not made public on their websites) to their response, the other 17 referred to the policy or code of conduct on their websites. Three more policies were found on the websites of the refusing companies. Together with the three from the companies that were not e-mailed, 30 useful observations were obtained from the Eurotop-100.

To increase the sample, the websites of the companies listed on the Dutch AEX index and the SWX Swiss Exchange which were not in the Ftse Eurotop-100 were screened for whistleblowing policies or codes of conduct covering this topic. An additional 19 observations were found on the Dutch websites, and seven on the Swiss ones. These additional 26 observations resulted in a total sample of 56 companies. These numbers have been summarized in Table I.

\section{Sample classification}

In the total sample, two groups of observations were distinguished: (1) separate, specific policy documents and statements on whistleblowing (sub-sample 1) and (2) whistleblowing clauses in corporate codes of conduct or codes of ethics (sub-sample 2). To get a better idea of the information the companies disclosed on whistleblowing, supplementary information found on their websites was also included in the observations. Of the 56-company sample, 26 had separate policy documents and 30 had a code of conduct or ethics describing the company's policy on the subject.

\section{Sample breakdown by country}

As can be seen in Table II, half of the 30 useful observations from the Eurotop-100 were from U.K. companies. Five observations were from German companies, three from Dutch and Swiss companies, two from Swedish companies and one from an Italian and French company. There were no useful 
TABLE I

Sample collection

\begin{tabular}{|c|c|c|}
\hline \multicolumn{2}{|l|}{ E-mails sent } & \multirow[t]{2}{*}{95} \\
\hline No reply/Confirmation of receipt only & -48 & \\
\hline Total number of responses & & 47 \\
\hline Refusals to cooperate & -10 & \\
\hline Details kept private & -8 & \\
\hline No policy & -5 & \\
\hline $\begin{array}{l}\text { Total number of useful responses } \\
\text { from Eurotop-100 }\end{array}$ & & 24 \\
\hline Responses & & \\
\hline Private policies mailed & 7 & \\
\hline Public policies mailed/referred to & 17 & \\
\hline $\begin{array}{l}\text { Useful material found on sites of } \\
\text { refusing/unreachable companies }\end{array}$ & 6 & \\
\hline $\begin{array}{l}\text { Total number of useful observations } \\
\text { from Ftse Eurotop-100 }\end{array}$ & & 30 \\
\hline $\begin{array}{l}\text { Additional programmes/Codes found } \\
\text { on Zurich Exchange }\end{array}$ & 7 & \\
\hline $\begin{array}{l}\text { Additional programmes/Codes found } \\
\text { on Amsterdam Exchange }\end{array}$ & 19 & \\
\hline Total number of useful observations & & 56 \\
\hline Observations & & \\
\hline Separate policies & 26 & \\
\hline $\begin{array}{l}\text { Codes of Conduct/Ethics and other } \\
\text { fragmented information on } \\
\text { whistleblowing }\end{array}$ & 30 & \\
\hline & & 56 \\
\hline Response rate (47/95) & & $49 \%$ \\
\hline Useful response rate $(24 / 95)$ & & $25 \%$ \\
\hline
\end{tabular}

responses from companies in Belgium, Denmark, Finland, Norway and Spain.

The Dutch and Swiss parts of the sample were substantially increased after the screening of these countries' national stock exchanges. Another 19 observations were found on Dutch company websites, most of which were separate policies. This can be explained by the rule of the Tabaksblat Code stating that the policy must be posted on the companies' websites. In Switzerland, almost all observations were codes with a whistleblowing provision. This is more surprising, as whistleblowing has so far not been part of the Swiss Code of Best Practice for Corporate Governance.

Because of the great number of additional policies found, the Dutch companies dominate sub-sample 1 by $65 \%$. Almost all of the other separate policies are from companies in the U.K. (31\%). The remaining one is from a Swiss company, and is quite brief, but still a distinct part of the company's website where it was found.

Sub-sample 2 is more evenly divided over the several countries. Most codes are from Swiss and U.K. companies (30 and 23\%, respectively). German and Dutch companies both account for 17\%. French (7\%), Italian and Swedish companies (both 3\%) constitute the rest of this sub-sample.

\section{Empirical results}

All policies and codes were investigated for their contents. The range of information from the policies and codes was classified into seven groups of items: (I) information concerning the policy's general contents, scope and tone; (II) the nature of the violations mentioned by the policy to be reported; (III) the contact persons to whom employees can directly report violations; (IV) reporting guidelines and formalities; (V) details concerning confidentiality and anonymity; (VI) details concerning protection from retaliation and (VII) details about the investigation of the complaint. All empirical findings are summarized in Table III.

\section{General contents, scope and tone}

Of the total sample, $23 \%$ and $21 \%$ made a statement about compliance with SOX and national corporate governance rules, respectively. Twenty percent specified or referred to a separate procedure for reporting accounting, auditing and internal control matters ("financial reporting matters"). Of the separate whistleblowing policies, $23 \%$ (11\% of the total sample) contained a full secondary procedure written for the purpose of appeal, in case reporting through the usual whistleblowing channel does not result in feedback or the response takes an unreasonably long time. One policy description (2\%) gave information on the results the policy achieved since its implementation.

All separate policies and $93 \%$ of the codes $(96 \%$ of the total sample) were applicable to all employees of the company. The remaining companies in the 


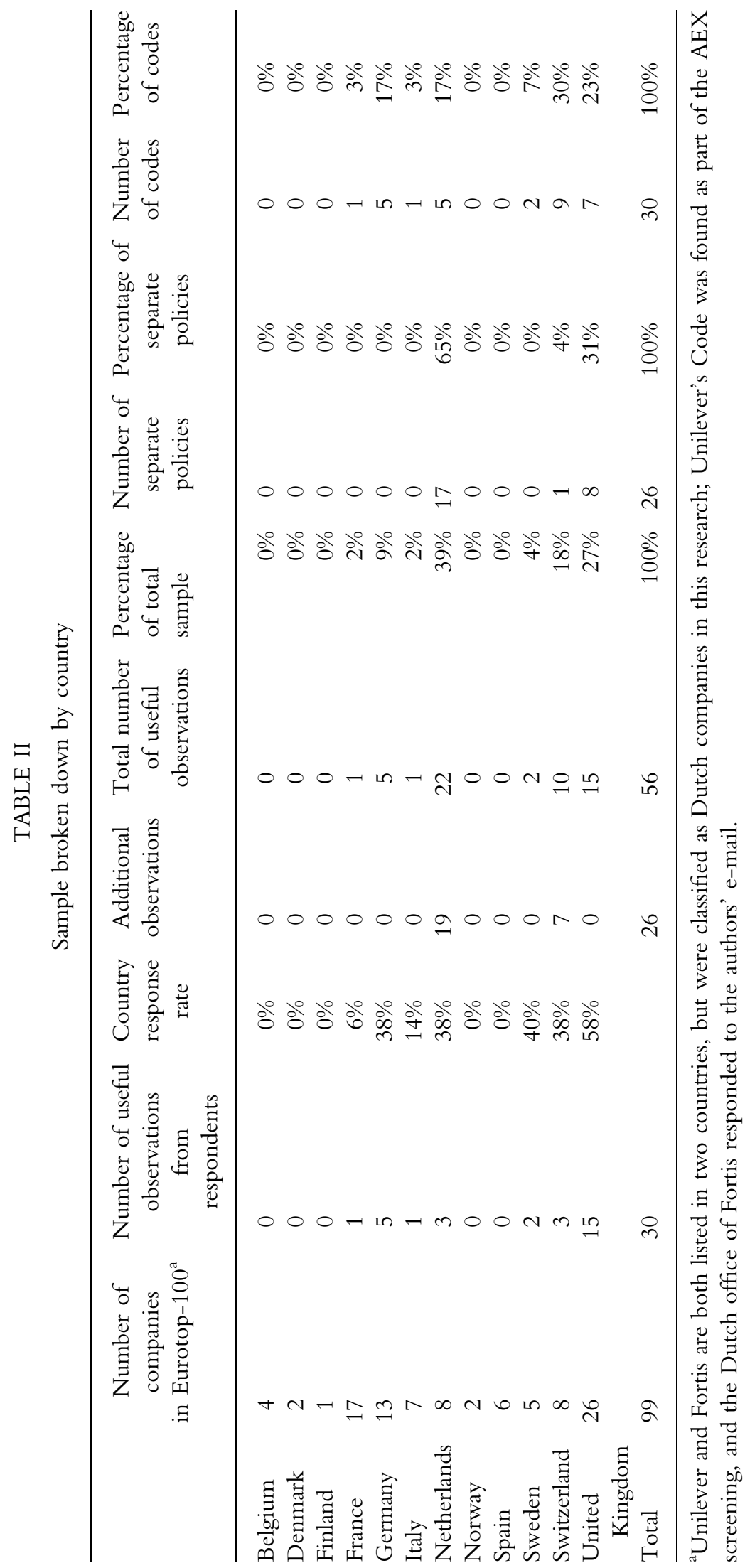


TABLE III

Content analysis

Total sample Sub-sample $1 \quad$ Sub-sample 2

$(n=56) \quad(n=26) \quad(n=30)$

I General contents, scope and tone

Stated that the policy or code applies to all employees

Stated that the policy or code applies to the entire group

Stated that reporting is a requirement or duty

Stated that employees are explicitly encouraged to report

Policy "supplements" or "does not replace other policies"

Stated that the policy was introduced in compliance

with Sarbanes-Oxley

Stated that the policy was introduced in compliance

with national regulations

Information was given about local application of the policy

Included a separate policy for senior and executive management

Included a separate policy for financial reporting matters

Stated that contractors may also report wrongdoing

The possibility of reporting is stated neutrally

Included a full secondary (appeal) procedure with

secondary contact

Stated that former employees can also report wrongdoing

Stated any results of the policy

$\begin{array}{lll}96.4 \% & 100.0 \% & 93.3 \% \\ 66.1 \% & 61.5 \% & 70.0 \% \\ 66.1 \% & 50.0 \% & 80.0 \% \\ 35.7 \% & 50.0 \% & 23.3 \% \\ 25.0 \% & 26.9 \% & 23.3 \% \\ 23.2 \% & 19.2 \% & 26.7 \%\end{array}$

$21.4 \% \quad 26.9 \% \quad 16.7 \%$

$\begin{array}{lll}21.4 \% & 19.2 \% & 23.3 \%\end{array}$

$\begin{array}{lll}21.4 \% & 7.7 \% & 33.3 \%\end{array}$

$\begin{array}{lll}19.6 \% & 11.5 \% & 26.7 \%\end{array}$

$\begin{array}{lll}17.9 \% & 30.8 \% & 6.7 \%\end{array}$

$\begin{array}{lll}17.5 \% & 11.5 \% & 13.3 \%\end{array}$

$\begin{array}{lll}10.7 \% & 23.1 \% & 0.0 \%\end{array}$

$\begin{array}{lll}5.4 \% & 7.7 \% & 3.3 \%\end{array}$

$\begin{array}{lll}1.8 \% & 3.8 \% & 0.0 \%\end{array}$

$27.8 \% \quad 28.1 \% \quad 27.5 \%$

II Nature of violations to be reported

General examples are given

("violations of code/law" etc.)

Violations of code or internal policies

Violations of the law or other regulations

$96.4 \%$

$28.1 \%$

$100.0 \%$

$\begin{array}{lll}96.4 \% & 92.3 \% & 100.0 \%\end{array}$

$\begin{array}{lll}66.1 \% & 76.9 \% & 56.7 \%\end{array}$

Financial reporting matters

Specific examples are given (criminal offences etc.)

$\begin{array}{lll}66.4 \% & 61.5 \% & 33.3 \%\end{array}$

$35.7 \% \quad 57.7 \% \quad 16.7 \%$

Failing to report a known violation is a violation in itself $\quad 30.4 \% \quad 42.3 \% \quad 20.0 \%$

Criminal offences

$19.6 \% \quad 38.5 \% \quad 3.3 \%$

Health and safety threats

$19.6 \%$

$34.6 \%$

$6.7 \%$

$16.1 \% \quad 26.9 \% \quad 6.7 \%$

Environmental issues

Corruption, mismanagement or abuse of authority

$12.5 \%$

$19.2 \%$

$6.7 \%$

$10.7 \%$

$15.4 \%$

$6.7 \%$

$\begin{array}{lll}10.7 \% & 23.1 \% & 0.0 \%\end{array}$

Misinforming of authorities or public bodies

$11.5 \%$

$6.7 \%$

$\begin{array}{lll}8.9 \% & 15.4 \% & 3.3 \%\end{array}$

Theft, misappropriation or misuse of company assets

$8.9 \%$

$7.7 \%$

$10.0 \%$

$7.1 \%$

$11.5 \%$

$3.3 \%$

Social misconduct, improper or unethical business conduct

$5.4 \%$

$7.7 \%$

$3.3 \%$

Security breaches

$5.4 \%$

$11.5 \%$

$0.0 \%$

Fraud by third parties

$5.4 \%$

$3.8 \%$

$6.7 \%$

Conflicts of interest

$5.4 \%$

$11.5 \%$

$0.0 \%$

"Irregularities of a general, operational or financial

$3.6 \%$

$7.7 \%$

$0.0 \%$ nature" 
TABLE III

continued

Total sample Sub-sample 1 Sub-sample 2

$$
(n=56) \quad(n=26) \quad(n=30)
$$

III Officials or bodies to whom wrongdoing should be reported

$(n=26)$

Direct or indirect supervisor

Compliance or Ethics officer

Contact details for specific contacts are given

Special hotline

(Chairman of) Supervisory Board or Board of Directors

Internal works council

IV Reporting guidelines and formalities

Stated that violations should be reported in sufficient detail in report to allow an investigation

Stated that violations may be reported in a native language, or that the reporting system is multilingual

Included a special reporting form

Requirement to explain suspicion without requiring evidence Specific details mentioned

Checklist for criteria of ethical behaviour

Graphical representation of reporting system

Ban on employees starting investigations themselves

Translation is required with the complaint

$\mathrm{V}$ Confidentiality and anonymity

Reported violations are treated confidentially

Violations can be reported anonymously

Anonymous reporting is discouraged or clearly not preferred

Circumstances given where confidentiality cannot be guaranteed

Publicity is allowed under clear conditions

(“do not go public unless...")

Publicity is not allowed without permission

No anonymity for third parties
$73.2 \%$

$53.6 \%$

$50.0 \%$

$37.5 \%$

$28.6 \%$

$25.0 \%$

$21.4 \%$

$21.4 \%$

$16.1 \%$

$16.1 \%$

$16.1 \%$

$12.5 \%$

$8.9 \%$

$7.1 \%$

$7.1 \%$

$5.4 \%$

$3.6 \%$

$1.8 \%$

$1.8 \%$

$1.8 \%$

$\begin{array}{ll}84.6 \% & 63.3 \% \\ 57.7 \% & 50.0 \% \\ 65.4 \% & 36.7 \% \\ 42.3 \% & 33.3 \% \\ 46.2 \% & 13.3 \% \\ 23.1 \% & 26.7 \% \\ 7.7 \% & 33.3 \% \\ 11.5 \% & 30.0 \% \\ 19.2 \% & 13.3 \% \\ 7.7 \% & 23.3 \% \\ 15.4 \% & 16.7 \% \\ 7.7 \% & 16.7 \% \\ 11.5 \% & 6.7 \% \\ 11.5 \% & 3.3 \% \\ 7.7 \% & 6.7 \% \\ 11.5 \% & 0.0 \% \\ 7.7 \% & 0.0 \% \\ 0.0 \% & 3.3 \% \\ 3.8 \% & 0.0 \% \\ 0.0 \% & 3.3 \%\end{array}$

$20.5 \%$

$22.1 \%$

$19.0 \%$

$\begin{array}{lll}14.3 \% & 26.9 \% & 3.3 \%\end{array}$

$\begin{array}{lll}14.3 \% & 19.2 \% & 10.0 \%\end{array}$

$\begin{array}{lll}8.9 \% & 19.2 \% & 0.0 \%\end{array}$

$\begin{array}{lll}7.1 \% & 15.4 \% & 0.0 \%\end{array}$

$\begin{array}{lll}7.1 \% & 15.4 \% & 0.0 \%\end{array}$

$\begin{array}{lll}7.1 \% & 3.8 \% & 10.0 \%\end{array}$

$\begin{array}{lll}5.4 \% & 11.5 \% & 0.0 \%\end{array}$

$\begin{array}{lll}3.6 \% & 7.7 \% & 0.0 \%\end{array}$

$\begin{array}{lll}1.8 \% & 0.0 \% & 3.3 \%\end{array}$

$\begin{array}{lll}7.7 \% & 13.2 \% & 3.0 \%\end{array}$

$\begin{array}{lll}78.6 \% & 96.2 \% & 63.3 \%\end{array}$

$64.3 \% \quad 69.2 \% \quad 60.0 \%$

$\begin{array}{lll}23.2 \% & 38.5 \% & 10.0 \%\end{array}$

$\begin{array}{lll}21.4 \% & 30.8 \% & 13.3 \%\end{array}$

$\begin{array}{lll}19.6 \% & 42.3 \% & 0.0 \%\end{array}$

$\begin{array}{lll}5.4 \% & 11.5 \% & 0.0 \%\end{array}$

$\begin{array}{lll}1.8 \% & 0.0 \% & 3.3 \%\end{array}$

$30.6 \%$ 
TABLE III

continued

Total sample Sub-sample 1 Sub-sample 2

$(n=56) \quad(n=26) \quad(n=30)$

VI Protection from retaliation

General statement ("There will be no retaliation")

Requirement of good faith

$73.2 \%$

$92.3 \% \quad 56.7 \%$

Retaliation is prohibited or not tolerated

$57.1 \%$

$61.5 \% \quad 53.3 \%$

Knowingly making false or malicious reports is punishable

$32.1 \%$

$19.2 \% \quad 43.3 \%$

Retaliation will be punished

$28.6 \%$

$50.0 \% \quad 10.0 \%$

Requirement of reasonable grounds or beliefs

$26.8 \%$

$34.6 \%$

$20.0 \%$

$26.8 \%$

$50.0 \%$

$6.7 \%$

No retaliation, even if complaint is unfounded

$16.1 \%$

$15.4 \%$

$16.7 \%$

Requirement of genuine or honest concerns, or legitimate reports

No immunity against punishment if complainant is involved

$12.5 \%$

$15.4 \%$

$10.0 \%$

$10.7 \%$

$11.5 \%$

$10.0 \%$

Liability towards subject of malicious complaint

$8.9 \%$

Requirement of no personal gain

$19.2 \%$

$0.0 \%$

$3.6 \%$

$7.7 \%$

$0.0 \%$

$3.6 \%$

$3.8 \%$

$3.3 \%$

No retaliation if complainant is involved in good faith

$1.8 \%$

$0.0 \%$

$3.3 \%$

Right of protection can be lost in case of external reporting

$1.8 \%$

$3.8 \%$

$0.0 \%$

$21.7 \%$

$27.5 \%$

$16.7 \%$

VII Investigation details

Guarantee of investigation or serious treatment of complaint

Obligation to cooperate in investigation

$\begin{array}{lll}57.1 \% & 80.8 \% & 36.7 \%\end{array}$

$19.6 \% \quad 26.9 \% \quad 13.3 \%$

Requirement of complaint log

Term for providing feedback to employee is given

$14.3 \%$

$26.9 \%$

$3.3 \%$

$14.3 \%$

Decision process of whether or not to investigate is described

$30.8 \%$

$0.0 \%$

$15.4 \%$

$0.0 \%$

$36.2 \%$

$10.7 \%$

sample only had a code of ethics that applied to employees in a senior managerial position, most often called Senior Financial Officers. Some other companies had such a code in addition to the normal policy, making the total proportion with a managerial code of ethics $21 \%$. In terms of company structure, $66 \%$ of the sample stated that their policy was Group-wide, covering all subsidiaries. Only $21 \%$, however, gave some specific information about local application of the policy by subsidiary companies. Exactly a quarter of the sample stressed that the policy does not replace other policies like personal grievance procedures. The procedures were accessible to contractors and former employees in $18 \%$ and $5 \%$ of the cases, respectively.

The tone of the policies was at least moderately authoritative in the majority of cases (66\%). These policies and codes speak of a requirement or duty to report violations, employees "must", "should" or "are expected to" report them. Thirty-six percent had an encouraging tone like "Employees are encouraged to report", "please report" or "feel free to report". A more neutral tone, stating that employees "can" or "may" report, was used by $13 \%$. These proportions add up to more than $100 \%$. This can be explained by several observations where the general policy had an encouraging or neutral tone, while the managerial code of ethics used in addition to it was more authoritative. This resulted in multiple tones for some companies.

\section{Violations to be reported}

In $96 \%$ of the sample, general examples of violations were given. Breaches of internal policies and codes of conduct were mentioned in all these cases, and violations of the law or other external regulations 
were included in 66\%. Although financial reporting matters caused the greatest scandals of the past years and triggered the creation of SOX and the national corporate governance codes, they were mentioned in only $46 \%$ of the sample. In $30 \%$ of the policies, it was made clear that failing to report a violation (remaining silent about a breach or concealing information about one) is a violation in itself.

More specific examples were included in 36\% of the sample. The most commonly mentioned examples were criminal offences, health and safety threats (both 20\%) and environmental issues (16\%). Failure to comply with legal obligations (11\%) and miscarriages of justice $(9 \%)$ were found only in the policies of U.K. companies. This is not surprising as both these violations were literally stated as disclosures qualifying for protection in the Public Interest Disclosure Act, together with criminal offences, health and safety hazards and environmental issues. The literal violation from the Tabaksblat Code, "irregularities of a general, operational or financial nature", was hardly found in any policy (4\%).

\section{People to directly report to}

The usual organizational hierarchy (one's direct superior/supervisor or the one above him/her) was by far the most common contact for reporting violations; these people should be reported to in $73 \%$ of all cases. Outside the hierarchy, slightly more than half of the sample $(54 \%)$ offered the possibility to report to a separate officer or committee that was specifically created for the purpose of compliance and ethics issues. A special confidential hotline (whether by phone or e-mail) was available in 38\% of all cases. Other contacts mentioned multiple times were the Supervisory Board (29\%), the Human Resources and Legal departments or officers (both 21\%), the Audit Committee, the Internal Audit and Corporate Governance department (all 16\%), and the Company Secretary (13\%). Any other contacts were in $7 \%$ of the sample, or less.

Exactly half of the sample specified the contact details (like an e-mail/postal address) for important contacts in the policy or code itself, and $9 \%$ referred to them being on the company website or intranet. A separate contact for reporting financial reporting matters was mentioned in a quarter of the observations.

\section{Reporting guidelines and formalities}

Several policies gave specific procedural rules that employees need to observe when they consider reporting a violation, and/or facilities to make reporting easier. Most of them (14\%) required employees to provide sufficient details of the reported violation to be able to investigate. Only $7 \%$, however, mentioned specific details to be reported. An equal part of the sample stated the requirement for reporting employees to adequately explain their suspicion, but solid evidence is never required. Two companies ( $4 \%$ of the sample) clearly required their employees not to conduct any personal investigation of the matter, and one German policy required a translation of the complaint if the employee's normal business language was not English or German.

Multilingualism of the reporting system (being able to report in one's native language) was the most frequently mentioned facility (14\%). Another facility was a special reporting form attached to the policy itself or provided on the company website (9\%). A checklist with criteria of ethical behaviour and a graphical representation of the reporting system were offered in a few cases (7\% and 5\%, respectively) to make the policy more understandable.

\section{Confidentiality and anonymity}

Most companies in the sample $(79 \%)$ clearly stated that their reporting system is confidential and all communication concerning reported violations is treated as such. Confidentiality can be broken from the perspective of the violator as well as the whistleblower. With respect to the identity of the violator, $20 \%$ of the policies contained the clear rule that employees are not allowed to make their concern public to third parties, unless investigation has been refused by all contact persons and all options for internal consultation have been exhausted. Another $5 \%$ stated that internal or external publicity is not allowed without prior permission from the usual contact persons. One may question the use of this condition, since external whistleblowing is essentially a last resort after the usual channels could or would not solve the problem. Making this act possible only by permission from these same channels is intuitively the same as unconditionally disallowing it. 
Circumstances where the company cannot guarantee complete confidentiality with respect to the identity of the whistleblower were mentioned by $21 \%$. Usually these circumstances were the event of a criminal investigation or a civil action for which a statement or evidence from the employee may be required.

Reporting a concern in complete anonymity, without revealing one's identity to a designated contact person, was possible in $64 \%$ of all cases. But in $23 \%$ it was clearly not the preferred way of action since anonymous reporting can "hinder or complicate investigations".

\section{Protection from retaliation}

Employees that consider reporting a violation must be protected from negative actions taken against them by the subject being reported as well as superiors afraid of negative publicity. The statement promising this protection can be made in multiple ways. Most policies (73\%) contained the general guarantee that there will be no retaliation, and/or employees will be protected. A rule prohibiting retaliation was found in $32 \%$, and a clear statement guaranteeing punishment of retaliation in $27 \%$. Several policies had more than one kind of statement, which explains why these percentages amount to more than $100 \%$.

However, the majority of companies restrict the kinds of reports that qualify for protection. Reports have to be "in good faith" (57\%), based on "reasonable grounds/beliefs" (27\%) or "genuine/honest/legitimate" (13\%). The concern may turn out unfounded after due investigation, but if it satisfies these conditions the employee should not be punished for reporting it. However, only $16 \%$ of the sample contained a statement that this indeed will not happen. The logical opposite is disciplinary action against knowingly false reporting and reports with malicious intent. This rule was included in $29 \%$ of the sample, and $9 \%$ stated that in such cases the reporting employee is liable for damages suffered by the subject of the report.

Surprisingly few policies indicate what will happen if the reporting employee was personally involved in the violation, since these people are an important group of potential whistleblowers. In 11\% of all cases, a rule is included stating that reporting one's own involvement will not give immunity against punishment of this violation, but only two companies (4\%) indicate that disclosure will be credited, and one managerial code of ethics promised there would be no retaliation if the manager was involved in good faith.

\section{Investigation details}

Investigation or serious treatment of a report was guaranteed in $57 \%$ of the total sample. Cooperation by managers and other employees with investigation procedures may speak for itself, but was only explicitly stated as an obligation in $20 \%$ of the policies. Other details were the requirement to keep a $\log$ of the investigation and a specific term for feedback to the employee (both 14\%). This feedback term was usually 2 months or 8 weeks. Finally, four policies $(7 \%)$ described a process to decide if the complaint will be treated seriously.

\section{Miscellaneous issues}

\section{Nomenclature}

For the separate policies in sub-sample 1, several different names were used. The most common titles were "Whistleblowing/Whistleblower Policy" and "Whistleblowing Procedure", in, respectively, 31\% and $19 \%$ of these cases. Four policies (15\%) were called "Rules of Conduct relating to Suspected (Financial) Irregularities" or "Code of Whistleblowing", suggesting more authoritative rules. Two programs $(8 \%)$ had a very specific name for the program that concisely signalled the underlying intentions: OpenTalk and Speak-OUT. The other policies had names like: "Malpractice Reporting Policy", "Corporate Ethics \& Compliance Programme", "Group Policy Statement Whistleblower Protection", "Public Interest Disclosure Policy" (stressing the link with the Public Interest Disclosure Act), "Internal Alert System", "Procedure for Complaints on Practices Violating Business Principles, HRM-, HSE-, and Security Policy Statements" and "Compliance Officer". The latter being a description of the function with the rules for 
contacting him/her found in the only Swiss observation in sub-sample 1.

\section{Similar formats}

The Dutch observations in sub-sample 1 seem to have developed a standard format. Five recent policies, introduced between August 2004 and March 2005, were strikingly similar in terms of contents (the only difference between them was a rule concerning amendments of the policy) and identically structured. Given the fact that there is no public format available that would explain the similarity of Dutch policies, this could indicate that Dutch companies have adopted a 'copy-and-paste' approach to the development of their whistleblowing policies. This approach may increase the efficiency of the development of these policies and also may result in a high level of uniformity between policies. However, it could also result in policies that are not adequately adapted to the situation of individual companies.

\section{Primary contacts}

In most policies, a primary and secondary contact was specified. The latter of these was to be consulted in case reporting to the primary contact is, for whatever reason, impossible. In some other cases, statements were made like "Report to person X, committee Y or officer Z". The authors regarded the contact persons in these statements as multiple instances of people to contact in the first instance.

Of the 76 first-instance contacts identified in the entire sample, 40 (53\%) were direct or indirect supervisors. Reporting to one's immediate superior or, if not possible, to one's superior's superior, is clearly preferred. The special Compliance function outside the usual hierarchy was mentioned in only 10 cases $(13 \%)$ as someone to report to in the first instance, whilst this function was available in 54\% of the sample (30 cases). Apparently, Compliance/ Ethics Officers and/or Committees are seen as someone to resort to if the employee feels uncomfortable with the usual course of action. The HR Manager/Department and corporate-governance functions like General Counsel were both specified in five cases (7\%). The other first-instance contacts mentioned multiple time, were the confidential help facility (e.g., a hotline), the Legal Officer/ Department, the Audit Committee and the Company Secretary.

\section{Contacts for financial reporting matters}

Separate procedures were sometimes explicitly stated for reporting matters of questionable accounting, auditing or internal control (referred to by the authors as "financial reporting matters"). In some other cases, a special contact person was given for reporting this kind of violations. This amounted to 14 instances of separate contacts for financial reporting matters. Six of these (43\%) were the Compliance function. The Audit Committee and the Internal Audit function were mentioned in four (29\%) and two cases (14\%), respectively. The Chairman of the Supervisory Board and the Chief Financial Officer were both stated once as the person to whom financial reporting matters should be reported.

\section{Appeal procedures and contacts}

Six policies in sub-sample 1 contained a full secondary procedure to be used in exceptional circumstances. In short, these circumstances were usually the following: the primary or secondary contact person is involved in the violation to be reported, has not responded to the report within the period specified in the policy or has suggested a different response period which is unreasonably long, the employee reasonably fears retaliation against his action, or a previously submitted report about the same violation has not had the effect of removing the violation. Also, an appeal to the secondary contact person about the longer response period or the lack of effect from the previous report must have failed before the secondary procedure may be resorted to. Five of these six policies were the Dutch ones with very similar structures and contents. Not surprisingly, these five all referred to the Chairman of the Supervisory Board as the one to consult in this "appeal procedure". In the sixth policy this was the Integrity Committee, a Compliance function. 
Effect of incorporation in a code of conduct and differences between countries

In the total sample, two groups of observations were distinguished: (1) separate, specific policy documents and statements on whistleblowing (sub-sample 1) and (2) whistleblowing clauses in corporate codes of conduct or ethics (sub-sample 2). Differences in the content of policies between both groups were tested using a series of $\chi^{2}$ tests. The results indicate that the principal difference between the groups is that the information provided in policies that are incorporated in code of conduct is less detailed. For five of the seven item-categories that were used in the content analysis, the results were statistically significant at at least the 0.05 level. For the categories 'General contents, scope and tone' and 'Officials or bodies to whom wrongdoing should be reported' no significant differences were found.

Using a series of $F$-tests, no significant differences were found between the content of policies in the Netherlands, Switzerland and the U.K. This result holds for each of the seven item-categories used in the content analysis.

\section{Conclusion and recommendations}

In this paper the information on whistleblowing provided by large listed European companies was analyzed. This information came in the shape of separate policy documents and codes of conduct or ethics containing a whistleblowing provision, as well as some fragmented supplementary information provided on company websites. Seven general categories of content, revisited in Table IV, were identified from the examined information.

Subsequently, a frequency table was presented to measure the details of the whistleblowing policies. In category I, the applicability to all employees, a group-wide scope and an authoritative tone ("employees are required to/must report") were found most frequently. The most common general examples of breaches were violations of codes and policies, and violations of law and external regulations. Where more specific violations were mentioned, these were most often criminal offences, danger to health or safety and environmental issues. The usual hierarchy was most frequently stated as the
TABLE IV

Basic structure of whistleblowing policy

\begin{tabular}{ll}
\hline I & $\begin{array}{l}\text { General contents, scope and tone } \\
\text { II }\end{array}$ \\
III & $\begin{array}{l}\text { Offure of violations to be reported } \\
\text { should be reported }\end{array}$ \\
IV & $\begin{array}{l}\text { Reporting guidelines and formalities } \\
\text { Confidentiality and anonymity }\end{array}$ \\
V & Protection from retaliation \\
VI & Investigation details \\
VII &
\end{tabular}

person (or one of the persons) to report to, but a separate compliance or ethics function outside the hierarchy was also often available. In several cases, the program was supported by a confidential hotline. In case specific procedural formalities and facilities were given for the act of reporting a violation, these were most frequently a requirement of sufficient detail and the possibility to report in one's native language. Confidentiality is commonly guaranteed, and anonymous reporting is possible in many cases, but also discouraged in some of them. Protection from retaliatory actions is always guaranteed, though retaliation is not very commonly stated as a prohibited and/or punishable act. Good faith is mentioned as a requirement for this protection quite often. The single most common detail concerning investigation of reports is the guarantee to do so. Further information in this category was not found in many cases.

Most separate policies were found in the Netherlands. Since the Tabaksblat Code requires companies to post the whistleblowing policy on their websites, this is not very surprising. Also, compared to the examined policies from the U.K., it seems the Dutch policies have become increasingly uniform as most of the ones that were introduced in 2005 are strikingly similar in terms of contents and structure. This development has not been observed in U.K. policies, even though the Public Interest Disclosure Act and the Combined Code on Corporate Governance have been effective for a longer period than the Tabaksblat Code. The third largest number of observations was found in Switzerland. These differ from the U.K. and the Netherlands in the sense that there were no extensive, official policy documents found. One policy, though not in a 
document of multiple pages, was separately posted on a company website. All other Swiss information on whistleblowing was found in codes of conduct or ethics and accordingly included in sub-sample 2 .

In general, the categorical framework created and the details identified in this study can be useful for companies to get an idea about the common contents of whistleblowing policies. It would be logical to use the seven categories of information in assembling such a document. Companies that do not have such a policy are also likely to look at the ones previously written. Several Dutch companies may have already done so, since their recently introduced policies are quite similar. These documents seem to reflect the present state of the art of whistleblowing, and organizations observing this may learn from it. Their format and contents may be used by companies as an example, but less common details found in the research sample may also be interesting.

Note, a standard policy is not necessarily the best solution; it may feel rushed and lack credibility to its readers when it looks like it was simply copied from another document. Also, the contents may not apply to all sizes of organizations. Companies will always have to carefully implement the procedure and clearly communicate that it works and how it works, through manuals and instructions to their employees. These may also be posted on the company website to send the same credible signal to the general public. But a standard format would probably result in more efficient policy formation and creation of the physical document, instead of having organizations "reinvent the wheel".

There is, however, also room for improvement. Despite the provision in the Tabaksblat code, not all Dutch policies in the sample were found on corporate websites. Three of them were e-mailed to the authors for the purpose of this study, one of which was partially published on the Internet. Four more internal documents were received from the U.K. Not making the whistleblowing policy public makes reporting by third parties impossible. Also, if nobody from the outside is able to read the policy, it does not contribute to effective corporate governance in society's view. So far, the Dutch Corporate Governance Code is the only code to include publication of the policy. To improve corporate governance in all of Europe, adoption of this rule in other countries may be advisable. Also, pan-European standard set- ters may consider introducing continent-wide rules or contributing to whistleblowing regulation in another manner.

Considering many policies were introduced as recently as 2004 and 2005, companies may not yet be ready for publishing the results. In this study, one U.K. company mentioned in its policy description the results the procedure had achieved since its implementation, in terms of the number of cases reported. In this single case the information was not given in a formalized policy document, but in a fairly informal description of the policy posted on the company's website. Such information, whether published by itself or in the annual report, may give interested outside parties an impression of how whistleblowing procedures actually affect a company after their introduction, and thus providing a better picture of the organization's corporate governance. This increased transparency, by reporting at least the number of times the procedure was used, may well affect the image of the company as a place where criminal and unethical acts do not go unreported, instead of the cynical picture of a place where these acts are condoned or covered up until somebody has the courage to blow the whistle to an outside party. Internal deliberations and future research should point out the appropriate level of detail of the information.

Finally, there is always a possibility that the employee who reports a violation was personally involved in it, or the employee has a strong suspicion but is not completely sure. In fact, the best-concealed violations may very well be the worst, and a report from one of the perpetrators or somebody with a "hunch" may be the only way to ever reveal them. Understandably, these people would have the greatest reservations towards reporting. This is why they need to be encouraged, and clarity is needed about what will happen to them if they do decide to blow the whistle. However, no more than nine companies (16\%) stated one or more specific rules for these particular employees. These nine policies guaranteed that no retaliation would take place against the reporting employee if the complaint (made in good faith!) would turn out unfounded. Six policies $(11 \%)$ specified that an employee involved in a reported violation would not result in immunity from punishment. This is logical, but still not encouraging. Only two organizations stated that 
"the fact that he/she has brought the concern to light will be taken into account" or the employee will be "given full credit for disclosing the violation voluntarily, in any subsequent decisions". One company made a statement in its code of ethics for senior financial officers that no retaliation would take place or be permitted if the officer "acted in good faith when making a report or being involved in a violation" (emphasis added). Rules like these are quite uncommon and adopting them on a larger scale may be beneficial to employees with reservations because of doubt or personal involvement, especially if one only finds out afterwards that what he/she did was not allowed.

Future research could compare whistleblowing policies from the United States with European policies, to find similarities and differences and perhaps make practical suggestions about what both sides of the Atlantic could learn from each other. The recent trouble with the implementation of SOX in France suggests that the "American way" of whistleblowing might be incompatible with the part of Europe that does not employ the Anglo-Saxon business model.

\section{Limitations}

Given the labour intensive research method used in this study, the research sample is limited to 56 companies from seven European countries, which limits the external validity of the study. Also, the sample selection method may result in some nonresponse bias, given the response rate of the original sample and the selection of additional observations. The Ftse Eurotop-100 is a list of leading European companies, and the analysis in this paper is thus limited to such companies. The observations from this list were supplemented by the largest listed Dutch and Swiss companies. Future research will have to point out the state of whistleblowing policies in smaller companies. A recent study by KPMG found that about half of the Dutch listed companies lack a whistleblowing policy, whilst $92 \%$ does have a code of conduct (KPMG, 2005). These policies are far more common, however, in the present study; 17 separate policies were found on the Dutch main index (AEX), where the 24 largest Dutch companies are listed. The KPMG study included 26 companies from all over the Dutch stock exchange. A concentration of whistleblowing procedures in the upper deciles of the exchange could be the most plausible explanation for the difference between KPMG's findings and the ones in the present study. Furthermore, the composition of the sample is slightly biased by the number of Dutch and U.K. companies in sub-sample 1. Logical explanations for this are the U.K.'s history of whistleblower protection through the Public Interest Disclosure Act, and the Dutch requirement of publishing whistleblowing policies on the Internet. The bias has been mitigated as far as possible by the observations in sub-sample 2 .

Finally, it should be mentioned that this study does not provide direct evidence on the effectiveness of governmental governance codes or company whistleblowing policies. To assess how these policies result in reducing the number of ethical violations and making sure committed violations are discovered, reported and solved internally, is another question. However, in order to address this question in a way that transcends anecdotic evidence, data on the content of whistleblowing policies as provided in this study is essential.

\section{References}

Arnold, D. and L. Ponemon: 1991, "'Internal Auditors" Perceptions of Whistle-Blowing and the Influence of Moral Reasoning: An Experiment', Auditing: A Journal of Theory and Practice 10, 1-15.

Association Française des Entreprises Privées and Mouvement des Entreprises de France: 2003, The Corporate Governance of Listed Corporations (AFEP and MEDEF, Paris).

Barnett, T., D. S. Cochran and G. S. Taylor: 1993, 'The Internal Disclosure Policies of Private-Sector Employers: An Initial Look at Their Relationship to Employee Whistleblowing', Journal of Business Ethics 12, 127-136.

Brass, D. J., K. D. Butterfield and B. C. Skaggs: 1998, 'Relationships and Unethical Behaviour: A Social network Perspective', Academy of Management Review 23(1), 14-31.

Brinkmann, J. A. and K. Ims: 2003, 'Good Intentions Aside: Drafting a Functionalist Look at Codes of Ethics', Business Ethics: A European Review 12, 265-274.

Brody, R., J. Coulter and P. Mihalek 1998, 'WhistleBlowing: A Cross-Cultural Comparison of Ethical 
Perceptions of U.S. and Japanese Accounting Students', American Business Review, 14-21.

Callahan, E. S. and J. W. Collins: 1992, 'Employee attitudes toward whistleblowing: Management and public policy implications', Journal of Business Ethics 11(12), 939-948.

Corporate Governance Committee (CGC): 2004, Belgian Code on Corporate Governance (Corporate Governance Committee, Brussels).

Corporate Governance Committee (CGC): 2003, The Dutch Corporate Governance Code: Principles of Good Corporate Governance and Best Practice Provisions (Corporate Governance Committee, The Hague).

Dechert 2005, Dechert OnPoint, 19 September 2005 (Dechert, London).

Dworkin, T. M. and M. S. Baucus: 1998, 'Internal vs. External Whistleblowers: A Comparison of Whistleblowing Processes', Journal of Business Ethics 17(12), 1281-1298.

Dworkin, T. M. and J. P. Near: 1997, 'A Better Statutory Approach to Whistleblowing', Business Ethics Quarterly 7, 1-16.

Ergeneli, A.: 2005, 'A Cross-Cultural Comparison of Ethical Behavior in Business Related Dilemmas: A Comparison among Turkish, Egyptian, Kirghiz and Kazak Marketing Employees', Problems \& Perspectives in Management 2, 135-147.

Eversheds: 2005, HR Euronews, September 2005 (Eversheds, London).

Farrell, B. J. and D. M. Cobbin: 2000, 'A Content Analysis of Codes of Ethics from Fifty-Seven National Accounting Organizations', Business Ethics: A European Review 9(3), 180-190.

Ferrel, O. C. and L. Gresham: 1985, 'A Contingency Framework for Understanding Ethical Decision Making in Marketing', Journal of Marketing 49, 87-96.

Financial Reporting Council (FRC): 2005, http:// www.frc.org.uk/corporate/combinedcode.cfm.

Financial Services Authority (FSA): 2003, The Combined Code on Corporate Governance (FSA, London).

Financiële Telegraaf: August 12, 2005, ING Bank Schikt met in opspraak geraakie directeur.

Gaumnitz, B. R. and J. C. Lere: 2002, 'Contents of Codes of Ethics of Professional Business Organizations in the United States', Journal of Business Ethics 35, 35-49.

Gernon, H: 1993, 'Discussion of an Investigation of the Reporting of Questionable Acts in an International Setting', Journal of Accounting Research (Supplement), 104-110.

Government Commission German Corporate Governance Code (GCGC): 2002, German Corporate Governance Code (Government Commission German Corporate Governance Code, Düsseldorf).
Jones, T. M.: 1991, 'Ethical decision making by individuals in organizations: an issue-contingent model', Academy of Management Review 16(2), 366-395.

Jubb, P. B.: 1999, 'Whistleblowing: A Restrictive Definition and Interpretation', Journal of Business Ethics 21, 77-94.

Kaptein, M.: 2004, 'Business Codes of Multinational Firms: What Do They Say?', Journal of Business Ethics 50, 13-31.

Kennedy Van der Laan Corporate Law Group: 2005, The Dutch Corporate Governance Code (Code Tabaksblat): An Update, August 2005 (Kennedy Van der Laan, Amsterdam), found on http://www.legal500.com/ devs/nether/cc/current.htm.

Kjonstad, B. and H. Willmott: 1995, 'Business Ethics: Restrictive or Empowering?', Journal of Business Ethics 14(6), 445-464.

KPMG: 2005, KPMG International Survey of Corporate Responsibility Reporting 2005 (University of Amsterdam and KPMG Global Sustainability Services, Amsterdam).

Larmer, R. A.: 1992, 'Whistleblowing and Employee Loyalty', Journal of Business Ethics 11(2), 125-128.

Lewis, D.: 2002, 'Whistleblowing Procedures at Work: What Are The Implications for Human Resource Practitioners?', Business Ethics: A European Review 11(3), 202-209.

Lewis, D.: 1997, 'Whistleblowing at Work: Ingredients for an Effective Procedure', Human Resource Management Journal 7(4), 5-11.

Lindsay, R. M., L. M. Lindsay and V. B. Irvine: 1996, 'Instilling Ethical Behavior in Organizations: A Survey of Canadian Companies', Journal of Business Ethics 15(4), 393-408.

Marnburg, E.: 2000, 'The Behavioural Effects of Corporate Ethical Codes: Empirical Findings and Discussion', Business Ethics A European Review 9(3), 200-210.

Mesmer-Magnus, J. R. and C. Viswesvaran: 2005, 'Whistleblowing in Organizations: An Examination of Correlates of Whistleblowing Intentions, Actions, and Retaliation', Journal of Business Ethics 62(3), 277-297.

Miceli, M. P. and J. P. Near: 1994, 'Relationships Among Value Congruence, Perceived Victimization, and Retaliation Against Whistle-blowers', Journal of Management 20(4), 773-794.

Miceli, M. P. and J. P. Near: 1988, 'Indicidual and Situational Correlates of Whistleblowing', Personnel Psychology 41, 267-281.

Ministry of Justice: 2004, Tabaksblat Code Enters into Force, 27 December 2004, http://www.justitie.nl/ english/press/press_releases/archive/archive_2004/30 1204Tabaksblat.asp.

Near, J. P. and T. M. Dworkin: 1998, 'Responses to Legislative Changes: Corporate Whistleblowing Policies', Journal of Business Ethics 17(14), 1551-1561. 
Near, J. P., T. M. Dworkin and M. P. Miceli: 1993, 'Explaining the Whistle-Blowing Process: Suggestions from Power Theory and Justice Theory', Organization Science 4(3), 393-411.

Near, J. P. and M. P. Miceli: 1986, 'Retaliation Against Whistle-blowers: Predictors and Effects', Journal of Applied Psychology 71, 137-145.

Near, J. P. and M. P. Miceli: 1985, 'Organizational Dissidence: The Case of Whistleblowing', Journal of Business Ethics 4, 1-16.

Near, J. P., M. Rehg, M. P. Miceli and J. R. Van Scotter : 2004, 'Developing a Model of The Whistle-Blowing Process: How Does Type of Wrongdoing Affect the Process?', Business Ethics Quarterly 14, 219-242.

Nitsch, D., M. Baetz and J. C. Hughes: 2005, 'Why Code of Conduct Violations go Unreported: A Conceptual Framework to Guide Intervention and Future Research', Journal of Business Ethics 57, 327-341.

O'Dwyer, B. and G. Madden: 2006, 'Ethical Codes of Conduct in Irish Companies: A Survey of Code Content and Enforcement Procedures', Journal of Business Ethics 63(3), 217-236.

PricewaterhouseCoopers: 2005, Protecting the Brand: The Evolving Role of Compliance Functions and the Challenges of the Next Decade.

Salem, G. R. and L. M. Franze: 2002, 'Corporate Compliance: The Whistleblower Provisions of the Sarbanes-Oxley Act of 2002', Insights: The Corporate and Securities Law Advisor, December 1, 2002.

Schmidt, M.: 2005, “Whistle Blowing” Regulation and Accounting Standards Enforcement in Germany and Europe-An Economic Perspective', International Review of Law \& Economics 25(2), 143-168.

Schwarz, M.: 2001, 'The Nature of the Relationship between Corporate Codes of Ethics and Behaviour', Journal of Business Ethics 32, 247-262.

Sims, R. R.: 1991, 'The Institutionalization of Organizational Ethics', Journal of Business Ethics 10(7), 493-506.

Sims, R. R. and J. D. Brinkmann: 2003, 'Enron Ethics (Or: Culture Matters More than Codes)', Journal of Business Ethics 45(3), 243-256.

Street, M. D.: 1995, 'Cognitive moral development and organizational commitment: Two potential predictors of whistle-blowing', Journal of Applied Business Research 11(4), 104-110.

Swiss Bankers Association (SBA): 2005, Swiss Federal Banking Commission's Circular on Internal Surveillance and Control: the Swiss Bankers Association Wants Made-toMeasure Solutions and not Blanket State Regulation, 3 August 2005 (Swiss Bankers Association, Basel).

Tabaksblat, M.: 2003, Speech door de voorzitter van de commissie corporate governance, mr. Morris Tabaksblat, bij de presentatie van de definitieve versie van 'De Nederlandse corporate governance code', 9 December 2003.

Thomas, J. Z. and D. L. Miller: 2005, 'Examining Culture's Effect on Whistle-Blowing and Peer Reporting', Business \& Society 44(4), 462-486.

Trevino, L. K.: 1986, 'Ethical Decision Making in Organizations: A Person-Situation Interactionist Model', Academy of management Review 11(3), 601-617.

Trevino, L. K. and B. A. Victor: 1992, 'Peer Reporting of Unethical Behavior: A Social Context Perspective', Academy of Management Journal 35, 38-64.

United Kingdom Parliament: 1998, Public Interest Disclosure Act 1998 (U.K. Parliament, London).

United States Congress: 2002, Sarbanes-Oxley Act of 2002 (U.S. Congress, Washington, DC).

Vandekerckhove, W. and M. S. R. Commers: 2004, 'Whistle Blowing and Rational Loyalty', Journal of Business Ethics 53, 225-233.

Van Es, R. and G. Smit: 2003, 'Whistleblowing and Media Logic: A Case Study', Business Ethics: A European Review 12(2), 144-150.

Weaver, G. R., L. K. Trevino and P. L. Cochran: 1999, 'Corporate Ethics Practices in the Mid-1990's: An Empirical Study of the Fortune 1000', Journal of Business Ethics 18(3), 283-294.

Harold Hassink, Meinderd de Vries
and Laury Bollen
Accounting and Information Management,
Maastricht University,
Tongersestraat 53,
Maastricht, 6211LM,
The Netherlands
E-mail: h.hassink@aim.unimaas.nl

